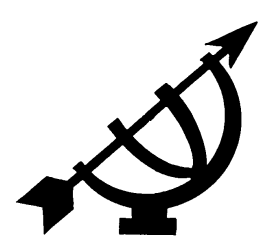

\title{
The moral challenge of poverty's impact on individuals
}

\author{
H.P.P. (Hennie) Lötter \\ Department of Philosophy \\ University of Johannesburg \\ JOHANNESBURG \\ E-mail: hpplotter@uj.ac.za
}

\begin{abstract}
The moral challenge of poverty's impact on individuals

In this article I want to substantiate the claim that poverty presents one of the most urgent moral challenges facing humanity. Poverty violates moral values about what constitutes a minimally decent human life broadly shared throughout the world and especially the standards for human living defined in Christianity. How can such a claim be substantiated? One has to judge the harmful impact of poverty on individuals and show that the moral repugnance of these effects on human beings makes it obligatory that poverty should be high on the agenda of all people. It is shown how devastating these effects of poverty can be for individual human beings and why poverty is such an affront to a person's dignity. In the light of the consequences poverty has for the dignity of its sufferers, it is judged that Christians have a strong moral responsibility to become involved with the plight of poor people.
\end{abstract}

\section{Opsomming}

Die morele uitdaging van die impak van armoede op individue

In hierdie artikel wil ek die standpunt verdedig dat armoede een van die dringendste morele probleme is wat die mensdom in die gesig staar. Armoede skend morele waardes rakende 'n minimale betekenisvolle menslike lewe wat regdeur die wêreld gedeel word en veral die standaarde vir menslike lewe wat in die Christendom uitgespel word. Hoe kan so 'n standpunt verdedig word? 'n Mens moet die skadelike impak van armoede op individue beoordeel en wys hoe die morele aanstootlikheid van hierdie gevolge dit verpligtend maak dat armoede hoog op 
die agenda van alle mense moet wees. Daar word aangetoon hoe verwoestend hierdie gevolge van armoede vir individue kan wees en waarom armoede so 'n aantasting van menswaardigheid is. In die lig van die gevolge van armoede vir die menswaardigheid van die slagoffers daarvan word geoordeel dat Christene 'n sterk morele verantwoordelikheid het om by die lot van arm mense betrokke te raak.

\section{Introduction}

Poverty is a major social-political issue. Throughout the world millions of people are suffering from poverty and its crippling effects, "Fifty-six percent of the world's population is currently poor: 1,2 billion live on less than $\$ 1$ a day and 2,8 billion live on $\$ 2$ a day" (Narayan et al., 2000:265). Poverty has been called "the world's most ruthless killer and the greatest cause of suffering on earth" (Gordon, 2002:74). The effects poverty has on human beings are so drastic that the phenomenon of poverty merits the undivided attention of governments, human and natural scientists, aid agencies, relief organisations, and citizens everywhere. One might say that people professing to be Christians have an added moral responsibility, as the emphasis on caring for vulnerable, suffering people is particularly strong in Christianity.

Although poverty devastates the lives of millions of people everywhere in the world, especially in developing countries, many nonpoor people ignore their plight. Why should all non-poor people in the world take poverty seriously? Why should they care about a "recognised evil" (Gordon et al., 2000:81) negatively affecting the lives of others around them? If some people face much greater risks of losing their lives than others as a result of avoidable circumstances, surely it calls for urgent moral action. Preventable death, for example, is one of the effects of poverty. Poor people can die for several more reasons than non-poor people, such as a lack of food, diminished resistance to disease as a result of inadequate diet, deficient or no medical care, and exposure to cold weather as a result of insufficient clothing or decrepit shelter. Preventable death is by far not the only effect of poverty; others include stunted physical or mental growth, lack of education, deprived opportunities for personal growth and development, and so on.

This article wants to substantiate the claim that poverty presents one of the most urgent moral challenges facing humanity, as poverty violates moral values about what it is that constitutes a minimally decent human life shared globally. How can such a claim be sub- 
stantiated? One has to judge the harmful impact of poverty on individuals and show that the moral repugnance of these effects on human beings makes it obligatory that poverty should be high on the agenda of all people. It is shown how devastating these effects of poverty can be for individual human beings and why poverty is such an affront to a person's dignity. In this article the focus is mainly on the moral unacceptability of the harm poverty causes to individuals' lives and not on the similarly serious effects on societies. The impact of the harms poverty inflicts on poor people's lives are judged by evaluating them in terms of moral values widely shared throughout human societies and some of the specific moral values of Christianity. These general moral values seem sufficiently uncontroversial not to need special defence in this article.

The fascinating story of the rich man and Lazarus in Luke 16:19-31 expresses what the core values of Christians regarding poverty ought to be. The moral of the story is as follows: The rich man stands accused for ignoring the plight of the desperately poor Lazarus despite the series of injunctions in the Old Testament that sets out how poor, vulnerable, and marginalised people must be treated. Throughout the Old Testament God's followers are instructed to take due care of poor people and to treat them respectfully.

The duties to poor people are reinforced in the New Testament. The general prescription to treat any suffering person as a neighbour is depicted in the story of the good Samaritan. In an intriguing way Jesus exhorts his followers to provide emergency relief to anyone in need thereof through his tale of judgement in Matthew 25:31-46. In this parable He so fully identifies with people in need that anything good done for them implies as if those things were done for Him as well. There can thus be no doubt that as far as poor people are in need and suffer, Christians have a moral responsibility to become engaged with taking care of them.

It might be useful to spell out the core values of Christianity that deal with poverty in slightly more detail ${ }^{1}$ as reasons in support of the argument made, i.e. that poverty poses special challenges to people committed to Christian values. God is portrayed in the Bible as the One who deeply cares for the vulnerable, weak, and marginalised

1 These core values are worked out in detail in the book Lux Verbi.BM will publish in 2008 (Lötter, [2008]). This article is based on material drawn from this book. 
people in society. He takes up their cause and demands that his followers should do the same. The ethical values prescribed to take care of the poor are particularly strong demands that are placed central to the meaning of being a follower of God. To take care of the poor (the vulnerable, weak, and marginalised members of society) belongs to the practical manifestation of belonging to God, showing that a person's faith in God is authentic and true. The reason for this emphasis is that God showed this kind of loving care for his followers when He pitied them in Egyptian bondage, in Babylonian exile, and in the bondage of sin everywhere in the world. Jesus emphasises God's care for the vulnerable in a dramatic way by fully identifying with vulnerable people as if He Himself has been each one of them. In response to God's merciful, loving care his followers must live their gratitude and worship through an ethical lifestyle pursuing justice towards all people.

Care for the vulnerable, weak, and marginalised people of society must become effective in the ways non-poor people give aid to them. The Bible knows of two kinds of aid that God's followers must render to people in need. One kind of aid is emergency poverty relief. People in desperate need of aid to satisfy basic needs must be helped without any questions being asked. This kind of aid is unconditional for people in desperate need thereof. Helping people in this way anchors in the core message of the Bible. The other kind of aid is aid to help poor people escape from their poverty and to restore them to become self-reliant, interdependent people similar to the others in society who are non-poor.

Poor people are not only in need of aid, but especially in need of humane treatment by non-poor people. Being poor is a public affair, and needing help from others for things most people provide for themselves is difficult to accept. Any action towards poor people that contains insults, humiliation, oppression, or exploitation makes life much more difficult for poor people. The Bible is clear that the dignity of poor people and their worth as human beings may not be violated in any way. Poor people are God's creation just like any other person and they therefore may not be treated differently from any non-poor person. How important this matter is in the New Testament becomes clear when Jesus identifies with the weak, vulnerable, and marginalised people to such an extent that relieving their needs is seen to be as if one is relieving the needs of Jesus Himself. No follower of Jesus would consider treating Jesus in a degrading or humiliating way. Thus people in need ought to be treated respectfully and lovingly. 
In the light of the strong emphasis in the Bible on (1) loving care for the vulnerable, weak, and marginalised people, (2) the great significance attached to helping poor people, and (3) the major importance of treating poor people with respect worthy of their dignity as God's children, it is not surprising that people causing poverty are judged severely. Stark contrasts between suffering poor people and exploitative rich people are rejected in no uncertain terms as totally unacceptable.

The strong emphasis on aid to poor people in the Bible has the intention of alleviating and eradicating poverty. This implies that poverty is not considered a condition God wishes people to stay in. God wants people's condition of poverty to be changed urgently through the help of his followers. Thus, anyone identifying with Christian moral values ought to have a sincere commitment to better the lives of poor people.

Someone might object that the positive outcomes poverty produces when people take up the challenge against poverty and succeed against all odds to make their lives meaningful are ignored. The fact that $I$ focus in this article on the negative impact of poverty on people means that I am directing attention to the harm poverty does to individual people. I am not denying the positive characteristics some poor people develop and display in dealing with these harmful effects. Poverty harms the lives of individuals. As in all cases of hardship or trauma, the harm that poverty does can elicit resilience, stimulate positive growth, and develop valuable qualities in people. I do not deny that poverty can have these positive effects on people, nor that poor people often have exemplary ways of dealing with poverty, or that people can give deep meaning to their experience of poverty.

Although some people who suffer deeply from poverty are victims, others show resilience by making clever plans in their efforts to survive (May, 1998b:18). The fact that individuals or groups of poor people "develop complex and innovative strategies to survive poverty and adversity" (UNDP, 1997:61) does not minimise the harms poverty inflicts on them, nor does it avert the terrible consequences poverty has on people who cannot successfully ward off its ravages. The bottom line is that poor people try their best "to cope with poverty, to resist it, and escape it" (UNDP, 1997:62). My focus is on what they are so desperately trying to avoid.

The harmful consequences of poverty on the lives of people vary and these variations are determined by factors such as the duration 
of poverty, its severity, the history and personal characteristics of its victims, and the level of social co-operation within the community they are part of. Poverty might not be the sole cause of certain effects, though it is often in connection with other causes. Poverty often triggers certain behaviour by providing the spark that sets things off, or poverty exacerbates existing problems. Although poverty researchers can point to clear links between poverty and certain negative effects on people and bad consequences for their lives, the exact link between poverty and such effects and consequences can only be determined empirically in each individual case (Halleröd, 2000:171).

In what follows, I want to sketch a profile of the impact poverty has on individual human lives. I will first give a general moral assessment of poverty, showing it to be a violation of poor people's dignity as human beings. I will then provide a detailed analysis of the specific, separate moral challenges that poverty engenders. In this article, I do not claim that all poor individuals are similarly affected by poverty's harmful impact. I merely show the negative effects that poverty has on some people of all races, creeds, languages, genders, ages, and origins throughout the world. My purpose in this article is not to assign blame or ascribe responsibility for the negative effects of poverty. I depict the possible consequences that poverty can have on its sufferers. These sometimes devastating consequences constitute a series of moral challenges deserving everyone's serious consideration. For Christians a depiction of these consequences ought to serve as a portrayal of challenges to deal with it successfully as well as opportunities to demonstrate God's love and respect adequately to people in need.

\section{The fundamental issue: poverty violates individual human dignity}

Poverty as a concept is almost uniquely applied to humans. It refers to a condition that causes its victims through lack of economic resources to live lives in which they cannot fully participate in the range of activities expressive of their nature as human beings, sometimes they may not even be able to maintain their physical health (Halleröd, 2000:167). To describe someone as poor thus indicates that a person has fallen below the standard of life thought appropriate for a human being in a specific society. The concept of poverty is generally taken to signify two levels at which persons' standard of living might have fallen below that of their peers. The concept of absolute poverty implies that a person does not have 
adequate economic capacities to provide food, clothing, shelter, security, and medical care to maintain their physical health. The concept of relative poverty signifies that although people have adequate economic capacities to provide food, clothing, shelter, security, and medical care to maintain their physical health, they cannot participate in any other activities regarded as indicative of being human in their society.

If poor people are forced through a lack of human resources to live a life judged by their peers as below the standards set for humans in their society, such humans experience their dignity denied. They are usually not regarded as human beings who ought to be treated with a certain minimum level of respect regarding their rights and concern for own well-being. If, in addition, their fellow citizens do not care about the degrading condition they face, poor people suffer the humiliation of being valued not worthy to care for as human beings. This lack of care adds another blow to their dignity, as they are not shown the consideration proper to humans in similar degrading circumstances. If Christians ignore their plight, poor people might view their status of being an image of God of no value. They might find no comfort in the way Jesus fully identify with their suffering in Matthew 25.

\section{The details: harms of poverty to individual lives}

Who are the "poor people"? Poverty is publicly observable in most cases. Poverty is easy to recognise, especially when poor people are encountered in their home environment. Some people come from families that have been poor for generations. Other people may be recently impoverished, due to retrenchment or a natural disaster, such as a drought, flood, or volcanic outburst. Children are often a significant proportion of the poor, as the proportion of children in poor societies is often higher than in more affluent societies. Women are particularly vulnerable to poverty, as especially oppressive patriarchal lifestyles increase their risks of becoming poor. Women are thought to "carry a disproportionate share of the problems coping with poverty" (Copenhagen Declaration, 1995:7).

Non-poor people cannot shrug off concerns about poverty as if they will never be affected. In this respect, poverty is like disability: every person faces the risk of becoming poor. John D. Jones (1990:16) says that non-poor people "face a variety of forces that can break into their world, disrupt it, tear it apart, and plunge them into poverty". A sudden natural disaster, like a flood, or a human disaster like war, can impoverish the most affluent members of society. 
Unexpected loss of employment, sudden death, or serious illness of an economically active household member can impoverish even rich people. More likely at risk of suffering poverty are those with few resources who cannot absorb the impact of sudden changes, like a downturn in the economy, retrenchment, death, disability, or illness of a household member. The case of Russia is informative. The rapid social, economic, and political transition since 1989 has left many Russians poor. Most poor Russians claim "they were not poor in childhood. Instead, they link the beginning of their decline with the beginning of perestroika, the process of economic and governmental reform launched in the 1980s" (Narayan \& Petesch, 2002:305). Poverty thus matters to every non-poor person, as a possibility they might encounter in future.

How does poverty harm people's individual lives? In what follows I present common trends found among poor people everywhere. I rely on comprehensive social science reports on the poverty of people in different parts of the world to identify the most often recurring patterns in poor people's lives all over the world.

\section{Poverty harms people's bodies}

In modern cultures lots of resources are invested to improve preventative, curative, and palliative medical care. In these cultures we morally reject any unnecessary, preventable suffering to the bodies and health of human beings. In Christianity, human bodies are seen as temples of God that are not to be violated. Throughout the Bible the emphasis is on providing food, clothing, healthcare, and shelter for the bodies of people in need. Individuals also have the responsibility to take care of themselves and their bodies, inter alia through avoiding (alcohol) abuse.

Poverty harms the bodies and health of human beings, especially in more severe cases. Poor people without sufficient economic resources to provide properly for their basic needs might easily suffer the consequences of an inadequate diet. Studies of the diets of poor people confirm that although only a small percentage of the poor do not have enough food to eat, most cannot afford a healthy and balanced diet (Wilson \& Ramphele, 1989:100; Murray, 1932:126). While some poor people can manage to include proteins and vegetables in their daily food intake, the diets of very poor people are severely deficient in basic foods needed for a healthy body (Wilson \& Ramphele, 1989:100). In 1901 Rowntree (1901:303) made the following remark that is still true today. He said that he did not intend "to imply that labourers and their families are chronically 
hungry, but that the food which they eat ... does not contain the nutrients necessary for normal physical efficiency". Not all cases of inadequate diets are caused by a lack of economic resources; sometimes poor people are ignorant about what a proper diet ought to consist of (Murray, 1932:127).

Researchers note how strikingly often they encounter poor health as a result of malnourishment among poor people (May, 1998b:118). Malnourished people are constantly tired, both physically and mentally (Murray, 1932:47). Their ability to concentrate, to work productively, and resistance to diseases are significantly reduced as a result of malnourishment (Murray, 1932:47). Many poor people, especially children, die from diseases that are triggered by malnourishment (Wilson \& Ramphele, 1989:100).

There is no doubt about the link between inadequate food intake, malnutrition, inadequate sanitation, and many of the diseases poor people suffer from (Wilson \& Ramphele, 1989:120; Kabir et al., 2000:707). The World Bank puts it simply: "the incidence of many illnesses ... is higher for poor people, while their access to health care is typically less" (World Bank, 2001:27). Narayan et al. (2000:53) state that poor people "dread serious illness within the family" more than anything else, as illness destroys the labour power and income of a productive household member.

Lack of sufficient income to provide for urgent needs affects the ability of poor people to have access to proper medical care. Most societies believe any member ought to have access to basic medical care available in their society in times of physical need. Being unable to afford doctors in private practice, poor people have to rely on public health services. They often do not even use these services, as the location of the public health facility might be too far away for them to travel, the reduced rates they have to pay might still be more than they can afford, and the hours that public health services are available might not be accessible to working poor people (May, 1998b:60, 61). As a result many poor people make use of traditional healers, herbalists, or self-medication instead (May, 1998b:118). Although good for some medical conditions, these alternative treatments are not necessarily effective for all.

Poverty related diseases are not the only source of harm to the bodies of poor people. III health can also be caused by dangerous or bad working conditions that often accompany low paying jobs (May, 1998b:118). Poor people often qualify only for jobs that are con- 
sidered physically risky where they have to do work that can lead to all kinds of injuries.

Some poor people are responsible for harming their own bodies. The widespread abuse of alcohol is a prime example. Poverty exacerbates alcohol abuse in certain poor communities and poor men abuse alcohol a lot more than women do. The destructive effects of alcohol abuse in many poor communities are well known.

\section{Poverty harms the mental well-being of people}

In Christianity the emphasis is on living one's life without allowing everyday cares and worries to weigh one down. A life filled with anxieties detracts from finding individual fulfilment through loving other people and worshipping God in the everyday events. Life in the 21st century is stressful enough for most people trying to cope with its everyday hassles. We morally reject any attempts to make life unnecessarily more complicated for people than it already is. However, people without sufficient food to eat, who do not have enough water for household use, do not have an adequate income, are at risk of disease and violence, and who do difficult work for low wages experience considerably more stress than other people without such problems. Lack of economic resources thus exacerbates stress in human beings.

Sometimes the uncertainties of whether they will have an income and how much of it will be gnawing at their peace of mind. Peter Townsend $(1979: 56,57)$ notes that for poor people there may be "major changes in the possession of resources both in the long term, over their entire life-cycle, but also in the short term, from month to month and even from week to week". He furthermore says that many people "have lived or are living under the constant threat of poverty and regard some of the resources flowing to them, or available to them, as undependable".

Researchers consistently find high levels of stress and feelings of frustration and anxiety among poor people (May, 1998b:50; May, 1998a:41). Worries about income, food, school fees, violence, keeping warm during winter, and the well-being of family members can negatively affect the mental state of poor people. Research suggests that poor people often dread the future, "knowing that a crisis may descend at any time, not knowing whether one will cope" (World Bank, 2001:135). 


\section{Poverty harms interpersonal/family relationships of people}

Human relationships of all kinds are crucial to develop the strong social aspects of our nature as human beings. We morally require human beings to engage in mutually beneficial relationships of different kinds. In Christianity strong family relationships and reciprocal care between neighbours are judged important. Within the Christian marriage mutual respect and compassionate caring are required from partners. Christians are furthermore enjoined to live at peace with all people.

Poverty can have a devastating impact on interpersonal and family relationships. The dangerous mix of stress about inadequate resources for the satisfaction of needs and the negative self-image formed from feelings of personal powerlessness can wreak havoc on interpersonal and social relationships. Patriarchal gender relations can become particularly strained when families suffer from poverty. In patriarchal marriages women take full responsibility for managing and executing household duties, while men make decisions concerning household income.

Poor women's unpaid work of household maintenance takes up most of their time and energy, leaving them exhausted. Consequently they are unable to take proper care of their children, to engage in activities to generate income or to utilise opportunities for education or self-improvement (May, 1998b:80). Women do not have sufficient time "to rest, reflect, enjoy social life, take part in community activities, or spend time in spiritual activities" (Narayan, et al., 2000a:34). Women thus do not get fair equality of opportunity to develop lives of their own as men do. Striking is the fact that even unemployed men with little to do will not assist women in domestic duties to ensure the maintenance or survival of the household (May, 1998b:102).

In general, most contemporary societies morally require protection for weaker and vulnerable people, and non-exposure to violence. In many poor communities women (and children) are more at risk from interpersonal violence than in other communities. The United Nations Development Programme (1997:31) judges that among the "worst threats of violence are those against women". Women in poor communities, according to responses in a survey and judged by cases reported to police services, suffer more from rape than women from more affluent areas (Wilson \& Ramphele, 1989:153; May, 1998a:130). Violence against women in the domestic sphere 
results from conflicts over food or money and the risk of such violence increases with rising levels of poverty and male unemployment (May, 1998a:131). Poor women are often trapped in abusive relationships where they endure violence as they depend on the abusive male for money, food, and shelter (May, 1998a:131). Many women see no way out of abusive relationships, as they have nowhere else to go. According to the UNDP, it "is estimated that a third of married women in developing countries are battered by their husbands during their lifetime" (UNDP, 1997:31). Researchers for the World Bank make the link between poverty and domestic violence even more explicit when they claim that, "rich and poor women alike are victims of domestic violence, but the incidence is often higher in poor households" (World Bank, 2001:137).

The scarcity of resources to address multiple needs raises the stakes involved in the distribution thereof within the household. Decision-making about, and management of scarce resources often lead to destructive conflicts in poor households, or exacerbate existing ones. Alcock (1993:137) says that the distribution of resources within households "may not be equitable and may leave many women living below the standards enjoyed by their partners".

\section{Poor parents and their children}

The moral sensitivities in many contemporary societies require that children be educated by their parents and treated decently so as to ensure that they have opportunities for optimal development as human beings. Christians are obliged to raise children with proper care and appropriate teaching in the light of the priority Jesus assigned to children in his ministry.

Children suffer many of the consequences poverty has on poor families. They are often part of unstable and broken families, or live apart from one or both their parents and are raised by people other than their parents. Lack of resources within households implies that children are often malnourished, poorly dressed, and without money for educational requirements (May, 1998a:30). Children are often forced to work to generate income and are thus deprived of educational opportunities, despite the fact that parents might recognise the value of education as a method to escape poverty (Narayan, 2000a:241).

The inability to continuously be a parent to one's children constitutes one form of neglect, besides others. When poor parents live with their children, they often do not have the energy to be involved in 
their children's lives to give spiritual, moral, emotional, or educational guidance (Terreblanche, 1977:76). Although the parents might be physically present, they are emotionally or psychologically absent from their children's lives. Often the only way they are involved is either by getting rid of their frustrations through their children or by enforcing overly strict and cruel discipline. Tired parents sometimes discipline children through cruel physical abuse, as they are too tired to take proper care of children through more appropriate verbal communication (Terreblanche, 1977:76). Frustration can be expressed through various forms of abuse and discipline is often arbitrarily enforced and accompanied with severe corporal punishment (Terreblanche, 1977:76). At times poor adults vent their anger and release their negative emotions of failure, frustration, and powerlessness through abusive and violent behaviour towards children (Terreblanche, 1977:76). A poor mother in Armenia provides an example when she says: "They reproach me for beating my children. But what should I do when they cry when they are hungry? I beat them to make them stop crying." (Narayan, 2000:238.)

Children are often victims of interpersonal violence in poor communities (May, 1998b:18). From a young age children's bodies bear the scars of the inability of adults to cope with too few resources. Researchers use strong language to refer to these aspects of poor children's lives. Children in poor households are seen to be "massively vulnerable to violence of many kinds" and are said to face "appalling conditions" (May, 1998a:30). Although these conditions include deprivation of basic necessities of life, the abuse of poor children "in all forms, is pervasive" (May, 1998b:18). Besides being subject to violence from relatives, poor children are exposed to many negative experiences, such as violence against women and substance abuse. They cannot fail to observe such behaviour in the cramped conditions of overcrowded homes and residential areas. The impact of these negative experiences on their early childhood leaves scars that can hardly be erased in later years (Terreblanche, 1977:76).

In many poor communities we find parents who have contradictory relationships with their children. On the one hand some parents place their children's well-being at risk by either requiring them to work from an early age or by venting their anger and frustration caused by poverty on their children. For some poor families "the need to provide additional income takes precedence over education" (Narayan et al., 2000:239). In the process, poor parents sometimes force their children "into the most risky forms of employment", some- 
times even prostitution (Narayan et al., 2000:239). On the other hand, through all their suffering, "poor men and women in communities around the world keep coming back to their deep longing for a better future for their children. "Whatever happens," they say, "let the children be all right" (Narayan \& Petesch, 2002:1).

\section{Poor people have stunted development}

In all societies human beings want babies to develop into healthy adults, capable of playing a role that suits the talents they were born with. Children ought to have opportunities and resources to transform them into adults who become full members of society, share responsibilities and contribute their share to the quality of life available for everyone. A common theme in Christianity is the idea that every person must develop their unique set of talents to become the human being God intended them to be. The tacit assumption behind this idea is that people will have sufficient resources and adequate opportunities to develop their god-given abilities appropriately.

That the physical and intellectual development of poor people could be stunted and retarded in various ways is almost too obvious to mention, yet as this fact is seriously neglected by non-poor people, it must be mentioned explicitly. Any person's development is closely linked to economic resources and publicly provided opportunities that make education and training possible. Even the quality of parental upbringing partially presupposes adequate economic resources.

In most societies people have strong moral views on the need for children to have enough food and a proper education. If growing poor children with developing bodies do not have adequate nutritious food, surely their development and growth will be stunted, as pointed out earlier. Poor people furthermore often find it difficult to acquire resources to provide schooling to their children, if adequate public provision is unavailable, inadequate, or costly. The World Bank (2001:27) states that in some poor countries, "most children from the poorest households have no schooling at all". In some poor societies children are required to earn money by working like adults and this happens most often "at the expense of schooling" (World Bank, 1990:31). Poor young people acknowledge the value of education and "express despair over the obstacles to obtaining education, especially secondary school fees, and link this directly to their poor employment prospects" (Narayan \& Petesch, 2002:65). 
To survive in contemporary fast-changing societies, most workers need to engage in continuous education, upgrade their skills, and acquire flexibility to adapt to new work conditions. Failure to do so often results in unemployment. Lack of economic resources makes it impossible for poor people to personally develop their employability, or their low-level jobs do not include education and training as standard benefits.

The link between poverty and inadequate personal development of individuals is clear. Gunnar Myrdal (1970:197) points out that in Pakistan "the ignorance of the masses stands as a complex of serious inhibitions and obstacles for economic development holding these countries down in poverty". The World Bank judges that poor people lack "human capital", as everywhere they have "a lower level of educational achievement than the population at large" (World Bank, 1990:31).

As human beings we also live in a broader society, in which governments at different levels provide services that require our involvement as prerequisite for enjoying their benefits. Part of our social development is to learn how to be informed about public services and how to become enabled to access them. Poor people often do not have opportunities to acquire such knowledge about the workings of their society nor to develop the competency to utilise them. They thus suffer from social illiteracy. Social illiteracy means not to have information about how your society works, not to know what services and goods you qualify for, and to be ignorant about ways to influence policy makers and public officials to legislate in your interest and do things for your benefit. This kind of illiteracy implies that poor people are often ignorant about assistance they are entitled to request, do not know which officials are in positions to provide them assistance and do not understand how to lobby for aid. Townsend (1979:849) notes that there are "severe problems in acquainting potential applicants with information about the conditions of benefit". Poor people are often unaware of policies made for their benefit, they do not know how to let policies work for them, and they do not know how to influence a government to take their interests seriously (May, 1998b:124). As a result available aid, assistance, and knowledge do not reach them. The comfort that their situation is being addressed by governments or non-governmenal organisations, albeit incompletely, never consoles them either.

The beaten-up person cared for by the good Samaritan illustrates that people's need is sometimes so overwhelming that they cannot 
access sources of help by themselves. They need others to unlock those sources for them, even though the assistance required might seem minimal to a healthy outsider. Their need and suffering disable them from doing so by themselves.

\section{Poverty increases people's vulnerability}

The strong duties to people in need found in Christianity reflect the ways Christians can reduce the vulnerabilities of suffering people. Christians are thus supposed to function as the shock absorbers of needy people. Persons' vulnerability depends on whether they can deal with the negative effects of shocks and changes that life throws at them and whether they can recover from those effects (May, 1998b:3).

The inabilities of poor people to procure sufficient resources to satisfy their basic needs make them more vulnerable to the shocks and changes of life (May, 1998b:3). In general, most human communities help vulnerable people to deal with, and recover from, the troubling, traumatic situations they face. However, such help and assistance are often not forthcoming, for whatever reason. The World Bank calls vulnerability "a constant companion" and a "constant feature" of poverty (World Bank, 2001:36, 77). Poor individuals, families, communities, or regions can be threatened by slowly occurring changes over a long term, such as drought or an economic recession. Drastic changes or shocks, i.e. "an unexpected event that leads to economic and social crisis" (Kabir et al., 2000:709), like floods or the death of productive family members, can be even more devastating. The World Bank says this threat, such as "an unfavourable turn of events, especially an unexpected one, can be catastrophic" (World Bank, 1990:34). Seasonal changes in normal annual cycles that threaten harvests can further increase poor people's vulnerabilities (May, 1998b:3). Note that poverty can make some people more vulnerable than others to life's normal shocks "for those with little, small shocks have big effects on wellbeing" (Narayan et al., 2000a:176).

\section{Poor people have problems with employment}

Christianity stresses the value of self-reliance through gainful employment in the context of a caring community with reciprocal relations. In addition Christian employers are instructed to pay fair wages to employees. 
A major cause of poverty is unemployment in cases where people have no social or family support. Poor communities are often characterised by the virtual absence of people who are formally employed (May, 1998a:75). To be unemployed does not necessarily imply that people are unskilled or uneducated. Although many poor people are unskilled, some have skills that are not in demand by the current economy. Many poor people all over the world realise the need to develop their employability by learning new skills for gainful employment (Narayan et al., 2000a:245). Even highly skilled people can become unemployed during times of economic recession, if employment opportunities shrink and companies start downsizing.

However, this does not mean that all poor people are unemployed and unable to find suitable jobs. Many poor people are employed, but the nature of their jobs contributes to their poverty. Some employed people do not earn wages that are sufficient to provide for their needs and those of their dependants (May, 1998a:4; Wilson \& Ramphele, 1989:54). Poor people are often full-time employees and evidence of the "problem of the working poor are still widespread today" (Alcock, 1993:13).

Townsend (1979:615) judges that there is not only "two broad states of employment and unemployment", but a "hierarchy of states from whole-time secure employment to continuous unemployment". Some forms of employment often do not provide the security of being permanent, as workers might be employed on a seasonal, temporary, or casual basis (May, 1998b:45 and Townsend, 1979: 589). Some lower status jobs have no prospects of increased salaries or status attached to them (Terreblanche, 1977:79). Townsend (1979:650) found that low pay is associated with negative aspects like "poor working conditions, small period of entitlement to notice, unsocial working hours, and lack of fringe benefits". Many of the inadequately paid jobs are furthermore done by poor people in dangerous conditions (Wilson \& Ramphele, 1989:72). Such jobs involve heavy physical effort, carry health risks, and expose people to injuries or death (May, 1998b:80).

Poor people are often inadequately qualified to be considered for better jobs. One reason might be that they do not - and did not value education as means to obtain a better job (Willcocks, 1932:19). This might be a less common reason today than decades ago. More common reasons for poor people's lack of skills are that they often find access to education difficult, as the costs involved are too high, the distance too far to travel, or the quality of facilities or 
teachers available to them, inadequate (May, 1998a:34; Wilson \& Ramphele, 1989:144).

\section{Poverty erodes the moral values of people}

Christianity judges a moral life to be very important. Believers are exhorted to obey God's commandments and to develop and inculcate specified virtues. Obedience to moral commands is taken as reflection of the quality of a person's faith.

Poverty erodes the moral values of people as desperation to make a living gives them an incentive to be immoral. They are too poor to be moral. If you need to lie or steal in order for you and your dependants to survive hunger and desolation, can you afford not to? In Bulgaria a poor person comments as follows: "Many people steal you can't starve to death" (Narayan \& Petesch, 2002:254). As poor people's bodies are often their only asset, they often try to protect its value through stealing when faced with constant hunger, especially their children's hunger (Narayan et al., 2000a:92). Poor people may argue that morally acceptable methods of earning a living did not work for them, they followed the rules of society in vain, therefore they are in a position where making a living through immoral means becomes a serious option (Willcocks, 1932:78). They do not have the material means to continue living a moral life (Terreblanche, 1977:70). In this way poverty becomes an instigator of moral decay (Willcocks, 1932:78).

Moral decay starts by desperate poor people being dishonest or telling lies in order to make a quick profit, to present a falsely good impression to prospective employers, or to get aid from government or relief organisations for which they do not qualify (Willcocks, 1932:78). Moral decay goes further when poor people decide to enter the "underground economy" by engaging in illegal trading of goods like alcohol, diamonds, drugs, or sex (Willcocks, 1932:83, 85; Wilson \& Ramphele, 1989:156). Others make stealing a career and steal food, cars, household goods, farm animals, water, or become poachers that steal wildlife on farms or in conservation areas (Wilson \& Ramphele, 1989:156; Willcocks, 1932:83, 84). Poor people confided to World Bank researchers that desperation and hunger sometimes force them to "anti-social and illegal activities", that included "to steal, drink, take drugs, sell sex, abandon their children, commit suicide, or trade in children" (Narayan et al., 2000a:60).

Once the moral decay of people sets off by contravening fundamental moral values for the sake of survival, the issue is whether 
they will stop in time before becoming serious criminals inflicting much greater harm on other people. If immoral behaviour leads to financial success and social power it might become so much more difficult to return to a moral lifestyle rather than slipping even deeper into immoral and criminal behaviour. For this reason, poor communities are often beset by serious problems of crime, from petty stealing to assault, rape, and murder (Terreblanche, 1977:63). Crime is often regarded as one of the "most tangible social consequences" of poverty (Wilson \& Ramphele, 1989:152).

High levels of crime by some of their own members have devastating effects on poor communities. Poor people may lose some of the few material assets they have and so be further disempowered from engaging in entrepreneurial activities aimed at improving their lives (May, 1998a:256; May, 1998b:18). Their quality of life can be reduced by high levels of fear and distrust, which also erodes social cohesion and co-operation (May, 1998a:257). As a result of illegal activities, Narayan et al. (2000a:60) state that "the household and often the wider community must face the fear and anxiety that these means of coping bring in their wake". Criminal behaviour and lack of resources create insecurity among poor people. When these feelings of insecurity combine with the frustrations poor people experience in their desperate circumstances, this often leads to various forms of abuse and violent crimes. Significant to note that poor communities suffer more from interpersonal crimes, like assault, rape, and child abuse than from property crimes (May, 1998a:130). A consequence of a high crime rate is that investors, able of creating employment opportunities or improving facilities and services, avoid those areas. Chances of reducing poverty are thus driven away.

\section{Conclusion}

In this article I argued in defence of the claim that the harmful impact of poverty on individuals directs urgent moral challenges to all nonpoor people, as the existence of poverty in a society violates widely shared moral values. I first gave a general moral assessment of poverty, showing it to be a violation of poor people's dignity as human beings. I then provided a detailed analysis of the specific, separate harmful effects that poverty can have on individual lives. I pointed out that poverty often does serious harm to poor people's bodies, relationships, morality, and social relationships.

With access to a full picture of the impact of the diverse harms that poverty does to the lives of individual human beings, non-poor people are called to account for their lack of response to the plight of 
poor people. Three moral challenges that follow from the above depiction of the impact of poverty on individuals are particularly relevant and urgent.

- Why do so many non-poor people of the world - especially so many Christians - sit back and allow fellow human beings to suffer from a condition causing such diverse forms of harm? To give aid to people in need and to help people avoid significant harms to some aspect of their lives seem to be generally accepted moral injunctions. So why do we, as individuals and as a society, so often avoid doing that for poor people? Why do we do nothing when individuals cry out as follows (Narayan et al., 2000:30): "Poverty is humiliation, the sense of being dependent, and of being forced to accept rudeness, insults, and indifference when we seek help."? Why do we not treat poor people as human beings, or as our fellow citizens, whom we publicly avow to be our moral equals, who should not be allowed to suffer in these ways? Why do so many of us not treat them as fellow humans created in God's image, as neighbours who need our love, care, and respect?

- Why do so many non-poor people exploit poor people and profit from their desperate situation? To exploit vulnerable people is judged to be a serious moral offence, so why do so many nonpoor people exploit the poor and so many others turn a blind eye? Why do Christians so often still react like the rich man reacted to Lazarus, as if they do not have all God's commands about the compassionate treatment of those in need?

- We owe our fellow citizens suffering from poverty consistent, serious, and competent reflection about these issues. We also have a god-given responsibility to find answers to these challenges. It is the very least we are obliged to do if we recognise them as human beings, if we respect their human dignity. Many Christian believers need to rethink their values and rediscover the priority of caring for fellow humans who suffer deeply from poverty. The impact of poverty on millions of individuals produces so much harm that non-poor Christians ought to treat the phenomenon of poverty as an emergency. 


\section{List of references}

ALCOCK, PETE. 1993. Understanding poverty. Houndmills: MacMillan.

COPENHAGEN DECLARATION. 1995. The Copenhagen declaration and programme of action. World summit for social development, 6-12 March 1995. New York: United Nations Department of Public Information.

GORDON, DAVID. 2002. The international measurement of poverty and antipoverty policies. (In Townsend, Peter \& Gordon, David. World poverty: new policies to defeat an old enemy. Bristol: Policy Press. p. 53-80.)

GORDON, DAVID, PANTAZIS, CHRISTINA \& TOWNSEND, PETER. 2000. Absolute and overall poverty: a European history and proposal for measurement. (In Townsend, Peter \& Gordon, David. Breadline Europe: the measurement of poverty. Bristol: Policy Press. p.79-105.)

HALLERÖD, BJÖRN. 2000. Poverty, inequality and health. (In Townsend, Peter \& Gordon, David. Breadline Europe: the measurement of poverty. Bristol: Policy Press. p.165-187.)

JONES, JOHN D. 1990. Poverty and the human condition: a philosophical inquiry. Leviston: Edwin Mellen Press.

KABIR, M.D. AZMAL, RAHMAN, ATAUR, SALWAY, SARAH \& PRYER, JANE. 2000. Sickness among the urban poor: a barrier to livelihood security. Journal of international development, 12(5):707-722.

LÖTTER, H.P.P. [2008]. When I needed a neighbour were you there? Christians and the challenge of poverty. Wellington: LuxVerbi.B.M. (To be published.)

MAY, JULIAN, ed. 1998a. Poverty and inequality in South Africa: report prepared for the Office of the Executive Deputy President and the InterMinisterial Committee for Poverty and Inequality. Durban: Glenwood.

MAY, JULIAN, ed. 1998b. Experience and perceptions of poverty in South Africa. Durban: Glenwood.

MURRAY, W.A. 1932. Die armblanke-vraagstuk in Suid-Afrika: verslag van die Carnegie-kommissie. Deel IV: Mediese verslag: die fisieke toestand van die armblanke. Stellenbosch: Pro-Ecclesia.

MYRDAL, GUNNAR. 1970. The challenge of world poverty: a world anti-poverty program in outline. Allen Lane: Penguin.

NARAYAN, DEEPA \& PETESCH, PATTI. 2002. Voices of the poor: from many lands. New York: Oxford University Press.

NARAYAN, DEEPA, CHAMBERS, ROBERT, SHAH, MEERA K. \& PETESCH, PATTI. 2000a. Voices of the poor: crying out for change. Oxford: Oxford University Press.

NARAYAN, DEEPA, PATEL, RAJ, SCHAFFT, KAI, RADEMACHER, ANNE \& KOCH-SCHULTE, SARAH. 2000. Voices of the poor: can anyone hear us? New York: Oxford University Press.

ROWNTREE, B. SEEBOHM. 1901. Poverty: a study in town life. London: MacMillan.

TERREBLANCHE, SAMPIE. 1977. Gemeenskapsarmoede: perspektief op chroniese armoede in die kleurlinggemeenskap na aanleiding van die Erika Theron-verslag. Kaapstad: Tafelberg.

TOWNSEND, PETER. 1979. Poverty in the United Kingdom: a survey of UNDP household resources and standards of living. London: Penguin.

see UNITED NATIONS DEVELOPMENT PROGRAMME 
UNITED NATIONS DEVELOPMENT PROGRAMME 1997. Human development report. New York: Oxford University Press.

WILLCOCKS, R.W. 1932. Die armblanke-vraagstuk in Suid-Afrika: verslag van die Carnegie-kommissie. Deel II: Psychologische verslag: die armblanke. Stellenbosch: Pro-Ecclesia.

WILSON, FRANCIS \& RAMPHELE, MAMPHELA. 1989. Uprooting poverty: the South African challenge. Report for the second Carnegie inquiry into poverty and development in Southern Africa. Cape Town: David Philip.

WORLD BANK. 1990. World development report. New York: Oxford University Press.

WORLD BANK. 2001. World development report. New York: Oxford University Press.

Key concepts:

harm

human dignity

poverty

responsibility

Kernbegrippe:

armoede

menswaardigheid

skade

verantwoordelikheid 